Research article

\title{
Electrochemically assisted photocatalysis: Highly efficient treatment using thermal titanium oxides doped and non-doped electrodes for water disinfection
}

\author{
Andreia Betina Kreuser dos Santos, Elis Marina Turini Claro, Renato Nallin Montagnolli, \\ Jaqueline Matos Cruz, Paulo Renato Matos Lopes, Ederio Dino Bidoia*
}

São Paulo State University (UNESP), Institute of Biosciences, Department of Biochemistry and Microbiology, Av. 24 A, 1515, Bela Vista, 13506-900, Rio Claro, SP, Brazil

\section{A R T I C L E I N F O}

\section{Article history:}

Received 5 June 2017

Received in revised form

22 August 2017

Accepted 3 September 2017

Available online 8 September 2017

\section{Keywords:}

Ag-doped electrodes

Electron drainage

Thermal oxides

Bacterial inactivation

Kinetics study

\begin{abstract}
A B S T R A C T
Electrochemically assisted photocatalysis (by electronic drainage) is a highly promising method for disinfection of water. In this research, the efficiency of photolytic oxidation using UV-A radiation and electrochemically assisted photocatalysis (with electric potential of $1.5 \mathrm{~V}$ ) was studied by using electrodes prepared by thermal treatment and doped with silver, for inactivation of Escherichia coli and Staphylococcus aureus. The Chick-Watson microorganism inactivation model was applied and the electrical energy consumption of the process was calculated. It was observed no significant inactivation of microorganisms when UV-A light or electric potential were applied separately. However, the electrochemically assisted photocatalytic process, with Ag-doped electrode completely inactivated the microbial population after 10 (E. coli) and $60 \mathrm{~min}$ (S. aureus). The best performing non-doped electrodes achieved 52.74\% (E. coli) and 44.09\% (S. aureus) inactivation rates after $60 \mathrm{~min}$. Thus, electrochemically assisted photocatalytic activity was not only effective for the inactivation of microorganisms, but also notably low on electrical energy consumption during the treatment due to small current and low electric potential applied.
\end{abstract}

(c) 2017 Elsevier Ltd. All rights reserved.

\section{Introduction}

Alternative microorganism inactivation processes are highly encouraged in current applications to substitute chlorine-based methods (Li et al., 2015). The introduction of nanostructured materials applied to water treatment processes has yielded highly efficient water decontamination (Molina et al., 2014). The Advanced Oxidation Processes (AOP), considered by Wang et al. (2015a) as a "green" advanced oxidation technology is a promising, efficient and versatile form of disinfection, based on the modification, degradation or mineralization of organic compounds through processes where electrons are the only reagent involved. The AOP is characterized by the formation of hydroxyl radicals $(\cdot \mathrm{OH})$ with high oxidation potential (Chaplin, 2014; Claro et al., 2016). Among various AOP, heterogeneous photocatalysis is one of the most widely used method to effectively destruct toxic compounds and

\footnotetext{
* Corresponding author.

E-mail address: ederio@rc.unesp.br (E.D. Bidoia).
}

inactivate microorganisms (Brugnera et al., 2013; Augugliaro et al., 2015; Byrne et al., 2015).

Heterogeneous photocatalysis is based on the activation of a semiconductor by sunlight or artificial light. Semiconductors such as titanium dioxide $\left(\mathrm{TiO}_{2}\right)$, zinc oxide $(\mathrm{ZnO})$, tungsten trioxide $\left(\mathrm{WO}_{3}\right)$, strontium peroxide $\left(\mathrm{SrO}_{2}\right)$, zirconium dioxide $\left(\mathrm{ZrO}_{2}\right)$, iron(III) oxide $\left(\mathrm{Fe}_{2} \mathrm{O}_{3}\right)$, cerium(IV) oxide $\left(\mathrm{CeO}_{2}\right)$, etc. have been extensively studied due to their catalytic properties and photocatalytic potential of contaminants degradation. The $\mathrm{TiO}_{2}$ is recognized as a promising semiconductor material for water purification (Scott-Emuakpor et al., 2012; Fan et al., 2014; Augugliaro et al., 2015).

From the photocatalytic standpoint, there are two main polymorphous phases of $\mathrm{TiO}_{2}$ : anatase and rutile (Yuangpho et al., 2015). The anatase phase is most commonly used due to its high photoactivity. Other studies demonstrated that pure rutile does not have photocatalytic activity (Ding et al., 2000). However, according to Molina et al. (2014), rutile photoactivity is dependent on three factors: preparation procedure (i), precursor (ii) or the organic 
compound used as the reducing agent (iii). Very little is known about the rutile phase as opposed to the extensive studies on the anatase phase.

These commonly used photocatalysts are often found immobilized or powdered. When a $\mathrm{TiO}_{2}$ photocatalyst film is immobilized on a conductive surface, a fixed positive electric potential is allowed under UV illumination. This process is known as electrochemically assisted heterogeneous photocatalysis (Dunlop et al., 2008).

The efficiency of photocatalytic processes is usually compromised by charge recombination. Hence, a reasonable strategy to improve catalyst efficiency is to modify the semiconductor structure by doping it with transition metal nanoparticles ( $\mathrm{Ag}, \mathrm{Cr}$, Fe for example). When the electrons from $\mathrm{TiO}_{2}$ after photonic excitation are imprisoned, there is a decrease followed by inhibition in the electron-hole pair $\left(\mathrm{e}^{-}\right) /\left(\mathrm{h}^{+}\right)$generated in photocatalyst surface (Hosseini et al., 2015; Bahadur et al. (2016). In addition, transition metals such as Ag have been extensively applied to the inactivation of microorganisms due to their antibacterial properties and biocompatibility (Brugnera et al., 2013; Pham and Lee, 2014; Parr and Kim, 2016).

Photocatalysis and electrochemically assisted photocatalysis have been widely described in the literature as an efficient alternative for inactivation of microorganisms such as Escherichia coli (Baram et al., 2007, 2011; Yu et al., 2008; Sun et al., 2014; Parr and Kim, 2016), Bacillus subitilis, Staphylococcus aureus, Klebsiella pneumonia, Cryptosporidium parvum oocysts (Cho et al., 2011; Vijay et al., 2013), Enterococcus faecalis and Clostridium perfringens spores (Dunlop et al., 2008).

The purpose of this research is therefore to evaluate the efficiency of photolytic oxidation (UV-A radiation only) and electrochemically assisted photocatalysis using non-doped $\mathrm{Ti} / \mathrm{TiO}_{2}$ either Ag-doped electrodes under UV-A irradiation and fixed electric potential and water samples containing Escherichia coli and Staphylococcus aureus.

\section{Material and methods}

\subsection{Preparation of the $\mathrm{Ti} / \mathrm{TiO}_{2}$ and silver-doped $\mathrm{Ti} / \mathrm{TiO} \mathrm{O}_{2}$ semiconductor}

The semiconductor (working electrode) was prepared according to Harper et al. (2001); Christensen et al. (2003, 2005) and Lopes et al. (2012). A titanium plate $(5 \mathrm{~cm} \times 5 \mathrm{~cm})$ was washed, immersed in acetone, dried and then calcined at $750{ }^{\circ} \mathrm{C}$. The entire procedure was repeated four times. The $\mathrm{TiO}_{2}$ film underwent heat treatment as proposed by Lopes et al. (2012). The $\mathrm{Ti} / \mathrm{TiO}_{2}$ electrode was removed from the muffle and cooled down to room temperature according to Christensen et al. (2003). Three electrodes were then setup with different calcination intervals to verify its impact during electrochemically assisted photocatalytic process, in which: Electrode 1: $10 \mathrm{~min}$; Electrode 2: $5 \mathrm{~min}$; Electrode 3: $15 \mathrm{~min}$.

A fourth electrode was doped with silver nitrate $\left(\mathrm{AgNO}_{3}\right)$. The electrode doping was performed with a $1.7 \% \mathrm{AgNO}_{3}$ solution (Merck), where the electrode remained immersed for approximately $5 \mathrm{~min}$ and then calcined at $750{ }^{\circ} \mathrm{C}$ for $10 \mathrm{~min}$. The procedure was repeated twice.

The thermal electrodes described were characterized using scanning electron microscopy (SEM) and X-ray diffraction spectrometry (XRD) by our research group (Lopes et al. (2012). Both techniques identified and characterized the formation of pure $\mathrm{TiO}_{2}$ films and $\mathrm{TiO}_{2}$ doped with silver $\left(\mathrm{Ag}-\mathrm{TiO}_{2}\right)$.

\subsection{Determining the photocurrent}

The electrical potential applied to photoelectrochemical processes was determined according to the photoactivity of the Ti/ $\mathrm{TiO}_{2}$ electrodes calcined for $10 \mathrm{~min}$. The photocurrent output was plotted against a $0-2.5 \mathrm{~V}$ potential range, at $10 \mathrm{mV} . \mathrm{s}^{-1}$, in the presence of $0.1 \mathrm{~mol} . \mathrm{L}^{-1} \mathrm{Na}_{2} \mathrm{SO}_{4}$. Measurements were taken using Autolab Potentiostat/Galvanostat. The $\mathrm{Ag} / \mathrm{AgCl}$ electrode $(\mathrm{KCl}$ $1 \mathrm{~mol} . \mathrm{L}^{-1}$ ) was used as reference electrode. The control current was established under the same potential, in the absence of light.

\subsection{Electrochemically assisted photocatalyst reactor}

The electrochemically assisted photocatalysis setup is shown in Fig. 1. It was composed of a working electrode and a counter electrode (circular $170.1 \mathrm{~cm}^{2}$ titanium net with $8.5 \mathrm{~cm}$ diameter) immersed in $250 \mathrm{~mL}$ of $0.08 \mathrm{~N}$ sodium sulfate solution $\left(\mathrm{Na}_{2} \mathrm{SO}_{4}\right.$ Merck PA) with $0.4 \mathrm{~mL}$ of bacterial suspension (final colony counts within the range of $3 \times 10^{2}$ colony-forming units $\left.-\mathrm{CFU} \mathrm{mL} \mathrm{m}^{-1}\right)$. The $\mathrm{Ti} / \mathrm{TiO}_{2}$ anode $(5 \mathrm{~cm} \times 5 \mathrm{~cm})$ was irradiated by two lamps in the UVA spectrum range ( $8 \mathrm{~W}$ black light bulb - Foxlux). Maximum wavelength peaked at $365 \mathrm{~nm}$, as shown in Fig. S1- supplementary materials. The electric potential was kept constant at $1.5 \mathrm{~V}$.

\subsection{UV-A radiation dose}

Bacterial inactivation using UV-A lamp had its radiation dose defined as the product of the energy intensity and the exposure time (Equation (1)).

$D=I \cdot t$

where $\mathrm{D}$ is the dose of ultraviolet radiation $\left(\mathrm{mW} . \mathrm{s} \mathrm{cm}^{-2}\right)$, I the radiation intensity $\left(\mathrm{mW} \mathrm{cm}^{-2}\right.$ ) and $\mathrm{t}$ is the exposure time (s).

The radiation intensity was measured by a spectrometer (Ocean Optic, USB-2000), at $0.2390 \mathrm{~mW} \mathrm{~cm}^{-2}$ in each lamp, as shown in Fig. 2. In total, $0.48781 \mathrm{~mW} \mathrm{~cm}^{-2}$ of radiation intensity was applied.

\subsection{Photocatalytic activity test}

The best microbial inactivation efficiency was verified through the different experimental conditions in Table 1.

\subsection{Bacterial inactivation experiments}

Inactivation assays were conducted with Escherichia coli CCT1457 and Staphylococcus aureus ATCCE538. It was inoculated with an inoculation loop, each bacterium in $50 \mathrm{~mL}$ of culture media

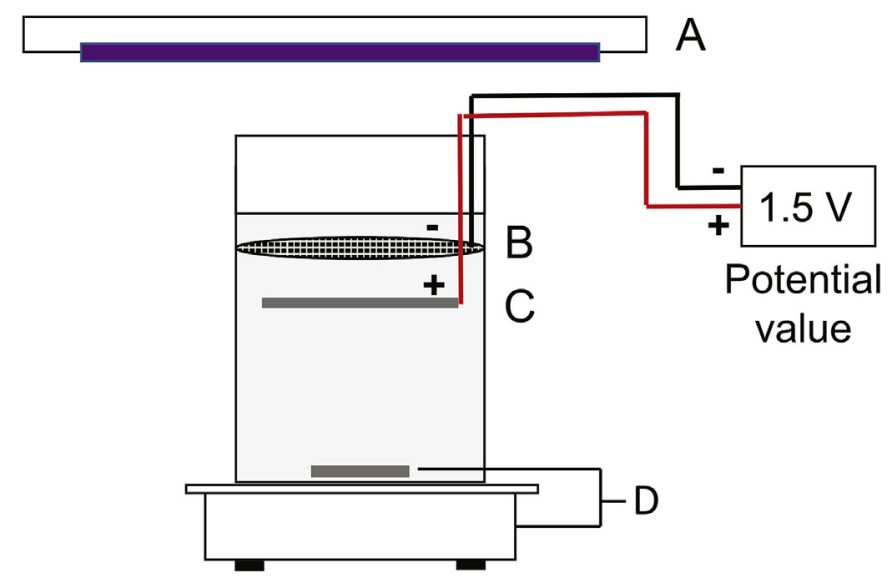

Fig. 1. Experimental setup: (A) Black light lamps UV-A; (B) Titanium counter electrode; (C) $\mathrm{Ti} / \mathrm{TiO}_{2}$ electrode; (D) Magnetic stirring. 


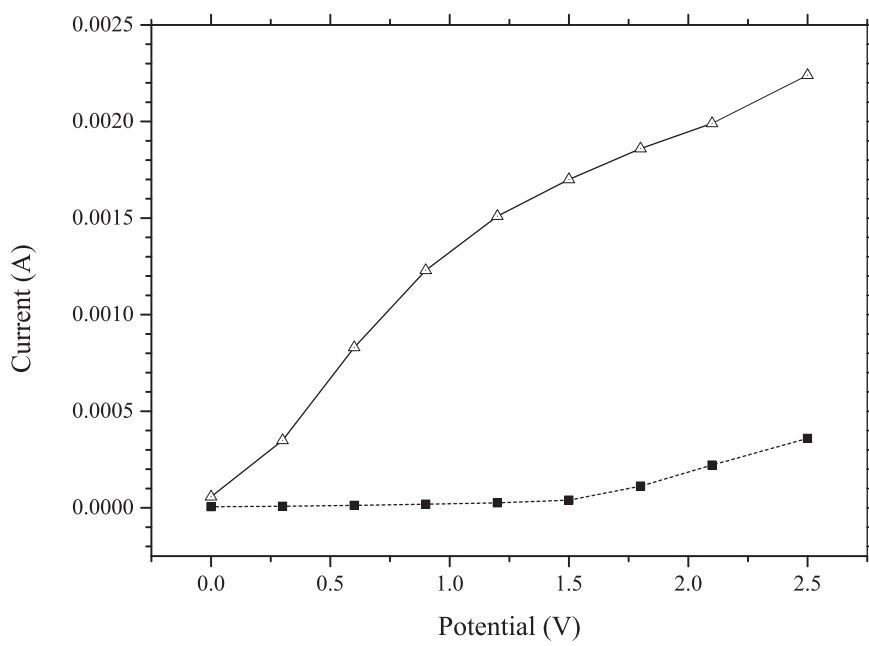

Fig. 2. Photocurrent density as a function of potential, point by point, obtained for the electrode produced thermally ( $\_$). Currents measured under illumination conditions $(\ldots \ldots+\ldots)$ currents measured in the absence of light conditions. light and fixed amount of catalysts. Consequently, equation (2) can be rewritten as equation (3).

$\ln \left(\frac{N}{N_{0}}\right)=-k^{\prime} t$

The constant ( $\mathrm{k}$ ) was obtained by linear regression analysis, and linearized by the OriginPro 9.0 software (OriginLab). According to the Chick-Watson Model, the slope is negative (-k). The N/No is the ratio of surviving bacteria after the contact time $t$, which can be expressed by Equation (4).

$\frac{N}{N_{0}}=e^{-k t}$

Thus, the inactivation percentage was calculated using equation (5):

Inactivation percentage $(\%)=\left(1-\frac{\mathrm{N}}{\mathrm{N}_{0}}\right) \times 100$

Table 1

Tests performed for inactivation of microorganisms.

\begin{tabular}{ll}
\hline Tests & Experimental conditions \\
\hline Test 1 - photolysis & UV-A radiation \\
Test 2 - electric potential & $\mathrm{TiO}_{2} /$ electric potential, $1.5 \mathrm{~V}$ \\
Test 2 - electrochemically assisted photocatalyst & Electrode/UV-A/electric potential, $1.5 \mathrm{~V}$ \\
\cline { 2 - 3 } & Electrode $1: \mathrm{Ti}^{\mathrm{TiO}} \mathrm{T}_{2}-10$ min of calcination \\
& Electrode $2: \mathrm{Ti}_{\mathrm{TiO}}-5$ min of calcination \\
& Electrode $3: \mathrm{Ti} / \mathrm{TiO}_{2}-15$ min of calcination \\
& Electrode $4: \mathrm{Ag}-\mathrm{Ti} / \mathrm{TiO} \mathrm{O}_{2}-10$ min of calcination \\
\hline
\end{tabular}

(nutrient broth - NB, Himedia, for E. coli and brain heart infusion BHI, Criterion, for S. aureus). The cultures were incubated for $24 \mathrm{~h}$ in orbital shaking at $180 \mathrm{rpm}$ at $35{ }^{\circ} \mathrm{C}$. Subsequently, $5 \mathrm{~mL}$ of each inoculum was centrifuged for $10 \mathrm{~min}$ at $80 \mathrm{rpm}(0.500 \mathrm{~g})$ and the precipitate was washed with $5 \mathrm{~mL}$ of solution containing $0.08 \mathrm{~N}$ $\mathrm{Na}_{2} \mathrm{SO}_{4}$.

Aliquots were collected at $0,10,20,30,40,50$ and $60 \mathrm{~min}$, which were then diluted in $0.85(\mathrm{~m} / \mathrm{v})$ saline solution and subsequently plated by the Pour Plate method. The dilution factor for microbial count was established at $10^{-4}$ in E. coli and $10^{-5}$ in S. aureus cultures. The plates were kept at $35{ }^{\circ} \mathrm{C}$ for $24 \mathrm{~h}$ and growth was quantified in $\mathrm{CFU} \mathrm{mL}^{-1}$. All experiments were performed in triplicate.

\subsection{Efficiency of inactivation level - kinetic study}

The classic microorganism inactivation model is described by Chick-Watson. According to this model the removal rate is directly proportional to the concentration of bacteria as a first-order reaction (Equation (2)).

$\ln \left(\frac{N}{N_{0}}\right)=-k[c]^{n} t$

where $\mathrm{N}$ is the colony count of the UV irradiated sample and $\mathrm{N}_{0}$ is the colony count of the sample before UV irradiation, $\mathrm{k}$ is the microorganism inactivation kinetic constant, $\mathrm{c}$ is the concentration of the disinfecting agent at time $\mathrm{t}$ and $\mathrm{n}$ the reaction order.

The concentration of the disinfecting agent can be considered constant though time in photocatalytic processes using artificial

\subsection{Experimental design}

The experimental approach used factorial design aiming at enhanced inactivation efficiency. The microbial inactivation factors were planned using the software Minitab 171.0 (Minitab Inc.). The 3 independent variables were: microorganisms (A), treatments type (B) and contact time (C) according to Table 2. The inactivation efficiency of microorganisms (\%) was selected as the response output (dependent variable).

The regression curve was rated by their coefficient of determination $\left(R^{2}, R^{2} a d j\right)$. Statistical significance was verified by ANOVA calculation through F-value and p-value. Model parameters were selected based on their probability values insertion within $95 \%$ confidence levels. Hence, it was evaluated the effects of each of the factors and their interaction on the overall efficiency of the photolysis, electric potential and electrochemically assisted photocatalytic with different electrodes.

\section{Results and discussion}

\subsection{Electrode photoactivity}

The electrode photoactivity was determined according to photocurrent, and measured in light and dark conditions. The Ti/ $\mathrm{TiO}_{2}$ electrode without irradiation presented no current up to the $1.5 \mathrm{~V}$ potential, thus guaranteeing the catalyst effect (Fig. 2). Electrochemical reactions (photoactivity) are added to the photocurrent above $1.5 \mathrm{~V}$. An increase in current occurred when the system was irradiated, hence indicating presence of photoactivity within the electrodes. Any potential higher than $1.5 \mathrm{~V}$ can change the 
Table 2

Independent variables of the factorial design for E. coli and S. aureus inactivation experiments.

\begin{tabular}{|c|c|c|c|c|c|c|c|c|}
\hline Independent variable & Factor & Range & & & & & & \\
\hline Microorganisms & A & E. coli & S. aureus & & & & & \\
\hline Treatments & $\mathrm{B}$ & Photolysis & Electric potential & Electrode 1 & Electrode 2 & Electrode 3 & Electrode 4 & \\
\hline Time (min) & $\mathrm{C}$ & 0 & 10 & 20 & 30 & 40 & 50 & 60 \\
\hline
\end{tabular}

electrode properties due to the deposition of undesirable materials, leading to losses in its photochemical capacity.

Thus, the electronic drainage at $1.5 \mathrm{~V}$ does not produce any changes in the working electrode, which in turn allows it to be used for several treatments. The Ag-doped electrode similarly presents no release of $\mathrm{Ag}$ ions in the solution due to a practically null electrolytic current. It was observed point by point photocurrent approach determined that the electrode was photoactive. Therefore, the estabilished electric potential $(1.5 \mathrm{~V})$ was set on further electrochemically assisted photocatalysis experiments.

\subsection{Bacterial inactivation}

The regression parameters for each treatment time according to using the Chick-Watson model is shown in Table 3. The k parameter is defined by $\mathrm{min}^{-1}$, due to its first order relation to microbial concentration.

According to Table 3, the results follow the Chick-Watson model. The N/NO and inactivation efficiency values for E. coli and S. aureus were calculated and plotted in Figs. 3 and 4, respectively.

Treatments using only photolysis and electric potential show that UV-A light applied separately to an electric potential result in negligible inactivation of the E. coli and S. aureus (Fig. $4 \mathrm{a}$ and $\mathrm{b}$ and Fig. 6). The UV-A lamps used in the experiment had low power $(8 \mathrm{~W})$ and low energy irradiation, thus unable to damage to microbial cells. UV lamps that emit radiation at $254 \mathrm{~nm}$ (UV-C) are the ones with the highest germicidal effect (Adhikari et al., 2015b). The sole application of electric potential on the electrodes also did not inactivate bacterial cells due to the low voltage $(1.5 \mathrm{~V})$ and current.

On the other hand, Fig. $3 a$ and b, Figs. 4 and 5 show that significant bacterial inactivation occurred when electrical potential was applied to $\mathrm{Ti} / \mathrm{TiO}_{2}$ electrodes combined with UV-A light. The treatment with Ag-doped electrode 4 yielded higher inactivation for both microorganisms. It was achieved complete inactivation after 10 and $60 \mathrm{~min}$ for $E$. coli and S. aureus, respectively. Electrode 1 had a $46.23 \%$ inactivation rate of $E$. coli, compared to the $16.23 \%$ inactivation of $S$. aureus after 60 min. Electrode 2 showed $39.12 \%$ inactivation of $E$. coli and $26.15 \%$ of $S$. aureus, while electrode 3 showed $52.74 \%$ and $44.09 \%$ inactivation of $E$. coli and $S$. aureus after $60 \mathrm{~min}$, respectively.

Certainly, $\mathrm{TiO}_{2}$ can be found in three polymorphic phases: anatase, rutile and brookite (Yuangpho et al., 2015; Wang et al., 2015b). From the catalytic point of view, anatase and rutile are the most studied forms. However, Lopes et al. (2012) produced Ti/ $\mathrm{TiO}_{2}$ thermal electrodes following the same protocols applied by
Bidoia's research group and found out by XRD that their thermally produced $\mathrm{TiO}_{2}$ film was in rutile form. The anatase form was not identified in the electrodes used. Thus, the electrodes produced thermally according to the same methodology used by Lopes et al. (2012), at a temperature of $750{ }^{\circ} \mathrm{C}$, were also in rutile form. Li et al. (2009) and Hanaor and Sorrell (2011) reported that the anatase phase is formed from lower temperatures (about $400{ }^{\circ} \mathrm{C}$ ) of calcination, whereas at $600^{\circ} \mathrm{C}$, the anatase-rutile phase transformation begins to emerge (Yuangpho et al., 2015).

The $\mathrm{TiO}_{2}$ semiconductor is characterized by valence bands and conduction bands. The region between bands is called band-gap. When a semiconductor is irradiated with ultraviolet radiation at energy values greater than its band-gap energy, electrons are generated in the conduction band and gaps in the valence band, thus creating the electron-hole pair $\left(\mathrm{e}-/ \mathrm{h}^{+}\right)$(Chong et al., 2010; Vijay et al., 2013; Chaplin, 2014).

The anatase phase is well known for its photocatalytic activity and its band-gap of $3.2 \mathrm{eV}$ is greater than in rutile forms $(3.0 \mathrm{eV})$, thus lowering the probability of the recombination between $\mathrm{e}-/ \mathrm{h}^{+}$ (Scanlon et al., 2013). However, according to Molina et al. (2014), rutile displays photoactivity depending on the preparation procedures, the precursors or the organic compounds used as reducing agent.

As seen in Figs. 3 and 4, the thermally produced electrodes presented photocatalytic activity for inactivation of both $E$. coli and S. aureus, which contradicts previous studies performed by Ding et al. (2000). In their study, pure rutile did not present photocatalytic activity, hence relying on the anatase phase for microorganism inactivation.

Molina et al. (2014) carried out a study producing glassimmobilized $\mathrm{TiO}_{2}$ thermal films for inactivation of $E$. coli ATCC 25922, with UV light at $364 \mathrm{~nm}$. When XRD was performed, the authors confirmed the presence of rutile phase in their film. They also confirmed the photocatalytic effect of the rutile phase for $E$. coli inactivation after 60-90 min.

Liu et al. (2003) produced $\mathrm{TiO}_{2}$ film in the rutile phase at a calcination temperature of $600{ }^{\circ} \mathrm{C}$ using photo-assisted sol-gel method. This method, compared to the traditional sol-gel method, accelerated the transformation of the anatase to the rutile phase. Rutile particles showed remarkable photocatalytic activity towards the decomposition of organic pollutants under ultraviolet irradiation. Furthermore, Butterfield et al. (1997) observed that the electrical potential coupled to a photocatalytic system subjected to UV irradiation caused an increase in the conductivity of titanium electrodes covered with $\mathrm{TiO}_{2}$. Krýsa et al. (2007) have pointed out

Table 3

Disinfection constant and R-squared values obtained by the Chick-Watson Model.

\begin{tabular}{|c|c|c|c|c|c|c|c|}
\hline \multirow[t]{2}{*}{ Treatment } & & \multicolumn{3}{|l|}{ Escherichia coli } & \multicolumn{3}{|l|}{ Staphylococcus aureus } \\
\hline & & Inactivation efficiency in $60 \mathrm{~min}(\%)$ & $\mathrm{k}\left(\min ^{-1}\right)$ & $\mathrm{R}^{2}$ & Inactivation efficiency in $60 \mathrm{~min}(\%)$ & $\mathrm{k}\left(\min ^{-1}\right)$ & $\mathrm{R}^{2}$ \\
\hline Photolysis & & 18.65 & -0.0034 & 0.751 & 13.62 & -0.0024 & 0.754 \\
\hline Electric potential & & 12.79 & -0.0022 & 0.961 & 16.68 & -0.0030 & 0.9678 \\
\hline \multirow[t]{4}{*}{ Electrochemically assisted photocatalysis } & Electrode 1 & 47.48 & -0.0109 & 0.986 & 16.23 & -0.0029 & 0.953 \\
\hline & Electrode 2 & 39.12 & -0.0082 & 0.983 & 26.15 & -0.0050 & 0.957 \\
\hline & Electrode 3 & 52.74 & -0.0124 & 0.985 & 44.09 & -0.0096 & 0.994 \\
\hline & Electrode 4 & 100 & -0.7106 & 1 & 100 & -0.1272 & 0.608 \\
\hline
\end{tabular}



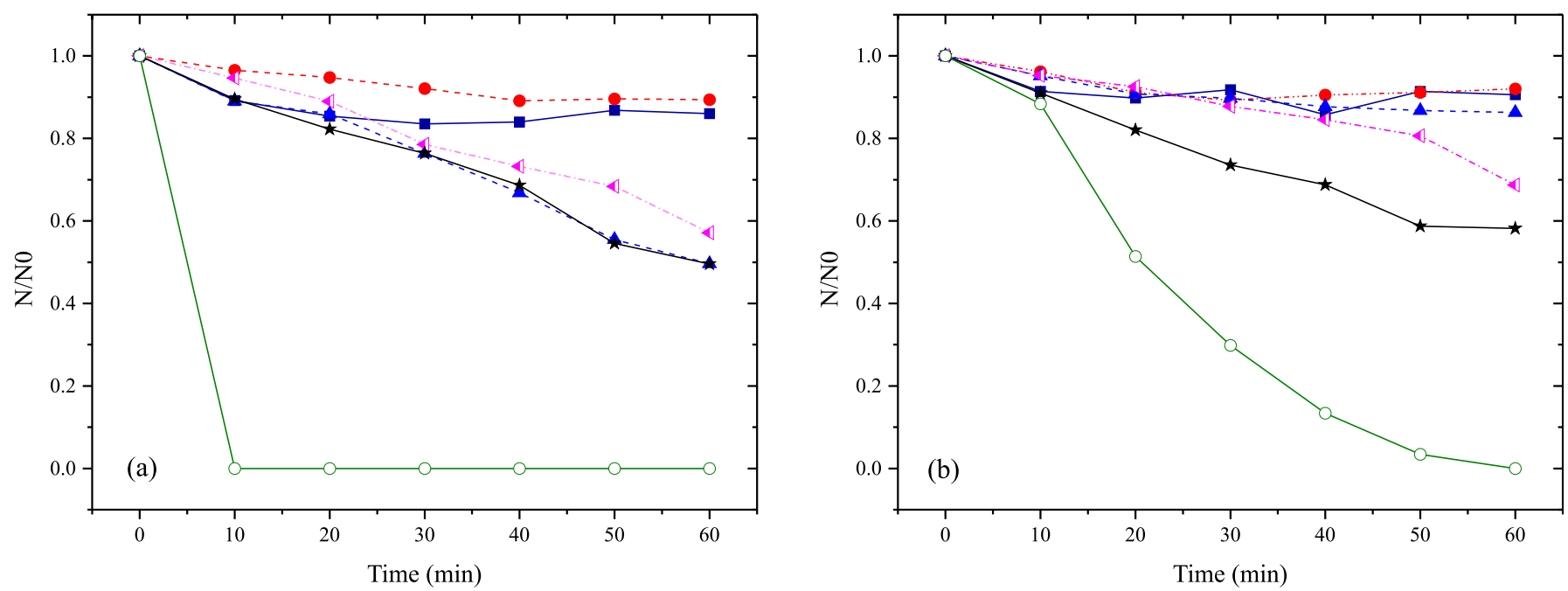

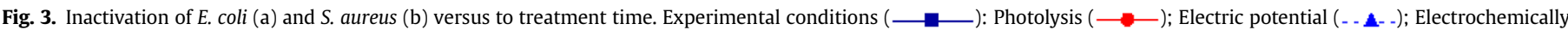

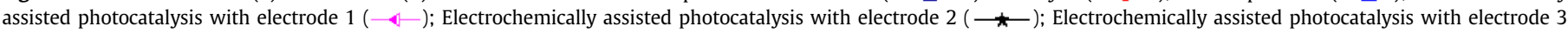
$(-\infty)$; Electrochemically assisted photocatalysis with electrode 4 .

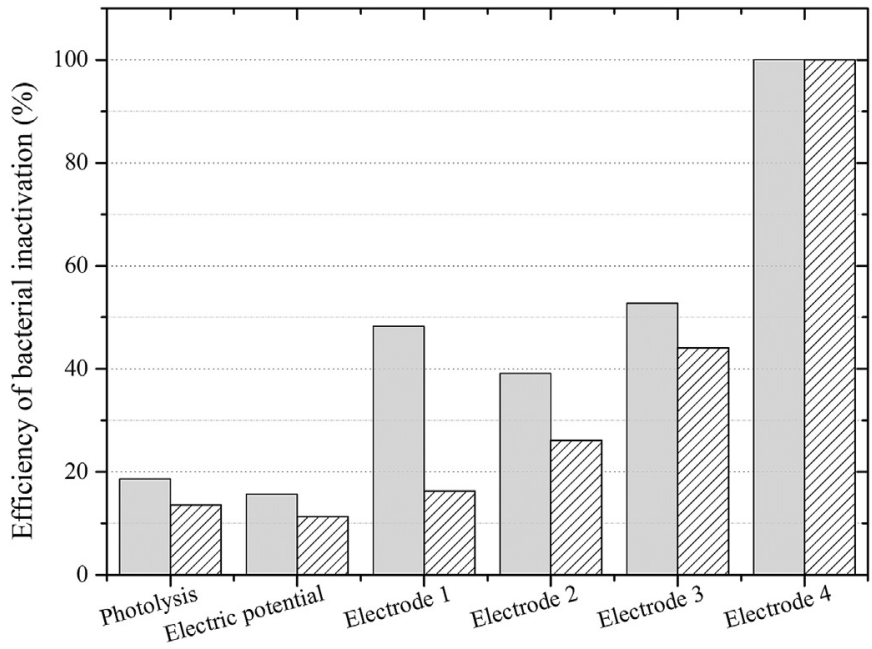

Fig. 4. Efficiency of bacterial inactivation after $60 \mathrm{~min}$ of photolysis, electrical potential and electrochemically assisted photocatalysis with different electrodes, where ( $\square$ ): E. coli ( Das); S. aureus.

that $\mathrm{TiO}_{2}$ layers thermally grown on a titanium substrate have high electrical conductivity, thus making them with better photocatalytic efficiency together with an electrical potential.

The applied potential in electrochemically assisted photocatalysis establishes a potential gradient into $\mathrm{TiO}_{2}$ films, favoring the separation of generated charges $\left(\mathrm{e}-/ \mathrm{h}^{+}\right)$and hence inhibiting the recombination process, which is the main limiting factor of quantum efficiency. This is due to the ratio of the number of electrons formed and the number of photons incident on the photocatalyst (Yang et al., 2005). As a result, electron drainage occurs, as well as an increase in the current density, both due to the migration of photogenerated electrons from the working electrode to the counter electrode (Quan et al., 2004). The concentration gradient favors the diffusion of species in solution to the surface of the working electrode $\left(\mathrm{TiO}_{2}\right)$ (Byrne et al., 2002). The decreasing rate of recombination of $\mathrm{e} / \mathrm{h}^{+}$pair causes an increase in the availability of more gaps and consequent formation of $\cdot \mathrm{OH}$ (Balasubramanian et al., 2004). This process ultimately leads to the increasing inactivation rate of microorganisms.

Harper et al. (2001) and Christensen et al. (2003) compared the efficiency of thermal and sol-gel electrodes for inactivation of E. coli. Both studies verified that the most efficient microorganism inactivation scenarios were promoted by thermal electrodes, due to thermal electrodes optimization effects caused by the electric potential, i.e. the decrease in $\mathrm{e}-/ \mathrm{h}^{+}$recombination rates. In the sol-gel electrode, the particles are smaller and the electric potential may not be sufficient to decrease the $\mathrm{e}-/ \mathrm{h}^{+}$recombination rates.

In addition to the electrical potential associated with $\mathrm{Ti} / \mathrm{TiO}_{2}$ electrodes, the Ag dopant is also important. The modification of the $\mathrm{TiO}_{2}$ surface with $\mathrm{Ag}$ nanoparticles provides an increase in the photocatalytic activity. The proposed effect of $\mathrm{Ag}^{+}$towards adsorption at catalytic surfaces is described by Equation (6). Under the presence of oxygen, the photocatalytic efficiency is even greater. According to Litter (1999) and Kumar et al. (2015) the $\mathrm{Ag}^{0}$ deposited on the $\mathrm{TiO}_{2}$ captures the electrons (used as surface traps) decreasing the recombination rates between the $\mathrm{e} / \mathrm{h}^{+}$pair. This process increases the number of "active sites" for adsorption of $\cdot \mathrm{OH}$, which consequently contributes to increase the oxidation efficiency of microorganisms (Parr and Kim, 2016; Ding et al., 2010). This is the reasoning for $\mathrm{Ti} / \mathrm{TiO}_{2}$ electrodes doped with $\mathrm{Ag}$ to be more efficient than non-doped thermal electrodes, as shown in Fig. 6 and 6 plots.

$\mathrm{Ag}^{+}$ads $+\mathrm{e}^{-} \mathrm{bc} \mathrm{Ag}_{\mathrm{ads}}$

Principal effects and interaction plots between treatment variables during inactivation of E. coli and S. aureus are shown in Figs. 5 and 6 . The data output from electrochemically assisted photocatalytic process showed greater $E$. coli (gram-negative) inactivation than $S$. aureus (gram-positive), as evidenced by the bacterial inactivation rate constants (k) calculated by Chick-Watson's law. The $\mathrm{k}$ parameter was higher for $E$. coli than $S$. aureus in all treatments (Table 3 ).

Such inactivation results are explained by variations in cell wall thickness between the two microorganisms. In gram-negative bacteria $E$. coli, the plasma membrane is surrounded by a cell wall composed of peptideoglycan, followed by an outer membrane of proteins, lipids and lipopolysaccharides. Its structure is often thinner than the cell wall of gram-positive bacteria S. aureus (Feng 


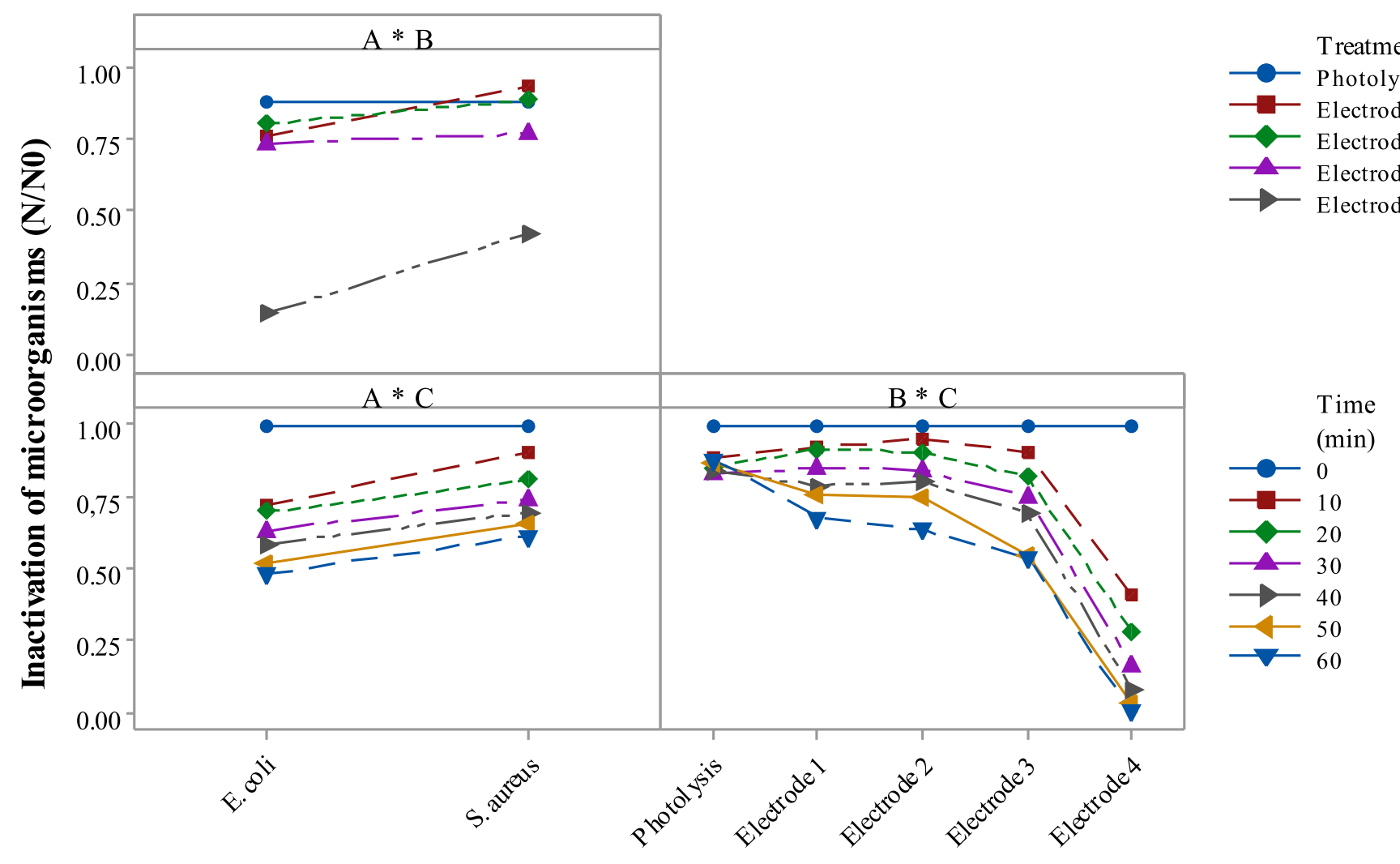

A

B

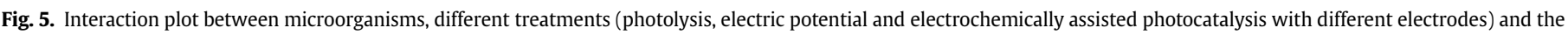
contact time for inactivation of E. coli and S. aureus. Where A: Microorganisms; B: Different treatments; C: contact time (min).

et al., 2000; Jung et al., 2008; Nakano et al., 2013). The microbial inactivation pattern found in this study was consistent with the ones found by other authors, such as Feng et al. (2000); Nakano et al. (2013); Pal et al. (2007) and Amininezhad et al. (2015).

According to Rincón and Pulgarin (2004), certain bacteria, especially gram-positive, have a very viscous capsule, which functions as a protection to the cellular wall. This external structure can be formed in response to environmental stimuli, exerting great influence on survival during the photocatalytic treatment with electrical potential. This additional bacterial resource may have been another factor responsible for an increased resistance of gram-positive $S$. aureus over gram-negative E. coli cells.

The electroassisted photocatalytic treatment combined processes related to bacterial inactivation, such as the direct absorption of UV radiation by the cells and the cellular destruction by $\cdot \mathrm{OH}$, with a powerful oxidizing agent generated by the degradation on the photocatalyst surface. Changes in the cell wall were therefore expected (Cho et al., 2011; Gusmão et al., 2009; Foster et al., 2011; Adhikari et al., 2015a; Grosser and Richardson, 2015). According to Matsunaga et al. (1985), the microbial death is due to the oxidation of coenzyme $\mathrm{A}(\mathrm{CoA})$ by the positively charged gaps, leading to the formation of dimeric CoA. In this study, the oxidation of CoA may have caused an inhibition of the cellular respiration, in the metabolic activity and consequent inactivation of the cells.

In this work, bacterial exposure to $\mathrm{Ti} / \mathrm{TiO}_{2}$ electrodes doped with $\mathrm{Ag}$ lead to many of those processes involving bacterial inactivation, mostly caused by electrochemically assisted photocatalysis. The inactivation by $\mathrm{Ag}$ nanoparticles also yielded higher inactivation rates in comparison to other electrodes (Figs. 5 and 6). Studies by Sondi and Salopek-Sondi (2004), Pal et al. (2007) and Adhikari et al. (2015a) showed that, similarly to $\cdot \mathrm{OH}$, the $\mathrm{Ag}$ damages cell membrane constituents. The Ag promotes structural changes and ruptures in the cell wall, thus interfering with the intracellular metabolic activity, which may be responsible to the cellular death results.

Liu et al. (2008) synthesized thin $\mathrm{Ag} / \mathrm{TiO}_{2}$ films and evidenced their bactericidal effects in $E$. coli, which was mostly related to ruptures in cell membranes. Five years later, Brugnera et al. (2013) determined that Ag nanoparticles exhibited enhanced antibacterial properties and biocompatibility among all antibacterial materials.

The disinfection of drinking water is well-known for reducing waterborne disease, as it is the greatest achievement of the 20th century on sanitation (Cutter and Miller, 2005; Plewa et al., 2017). The on-going search for alternative disinfection methods is therefore a relevant challenge (Meireles et al., 2016). The development of novel methods for water and wastewater recycling are worldwide priorities since its implementation for the disinfection of drinking water are crucial for public health (Plewa and Richardson, 2017).

\subsection{Electric energy consumption}

Electroassisted photocatalysis can be commercially applicable towards water treatment, as long as the studies focus photoefficiency improvements (Parent et al., 1996). As seen in Table 4, the inactivation of $100 \%$ of $E$. coli with the Ag-doped electrode required $10 \mathrm{~min}$ of treatment and $286.86 \mathrm{mWs} \mathrm{cm}^{-2}$ of ultraviolet radiation. The energy consumption of this process from the UV-A lamp was $0.018 \mathrm{kWh} \mathrm{m}^{-3}$. The inactivation of $100 \%$ S. aureus with the Ag-doped electrode took $60 \mathrm{~min}$ and $1721.16 \mathrm{mWs} \mathrm{cm}^{-2}$ radiation dose with $0.108 \mathrm{kWh} \mathrm{m}^{-3}$ energy consumption from UV- A. 


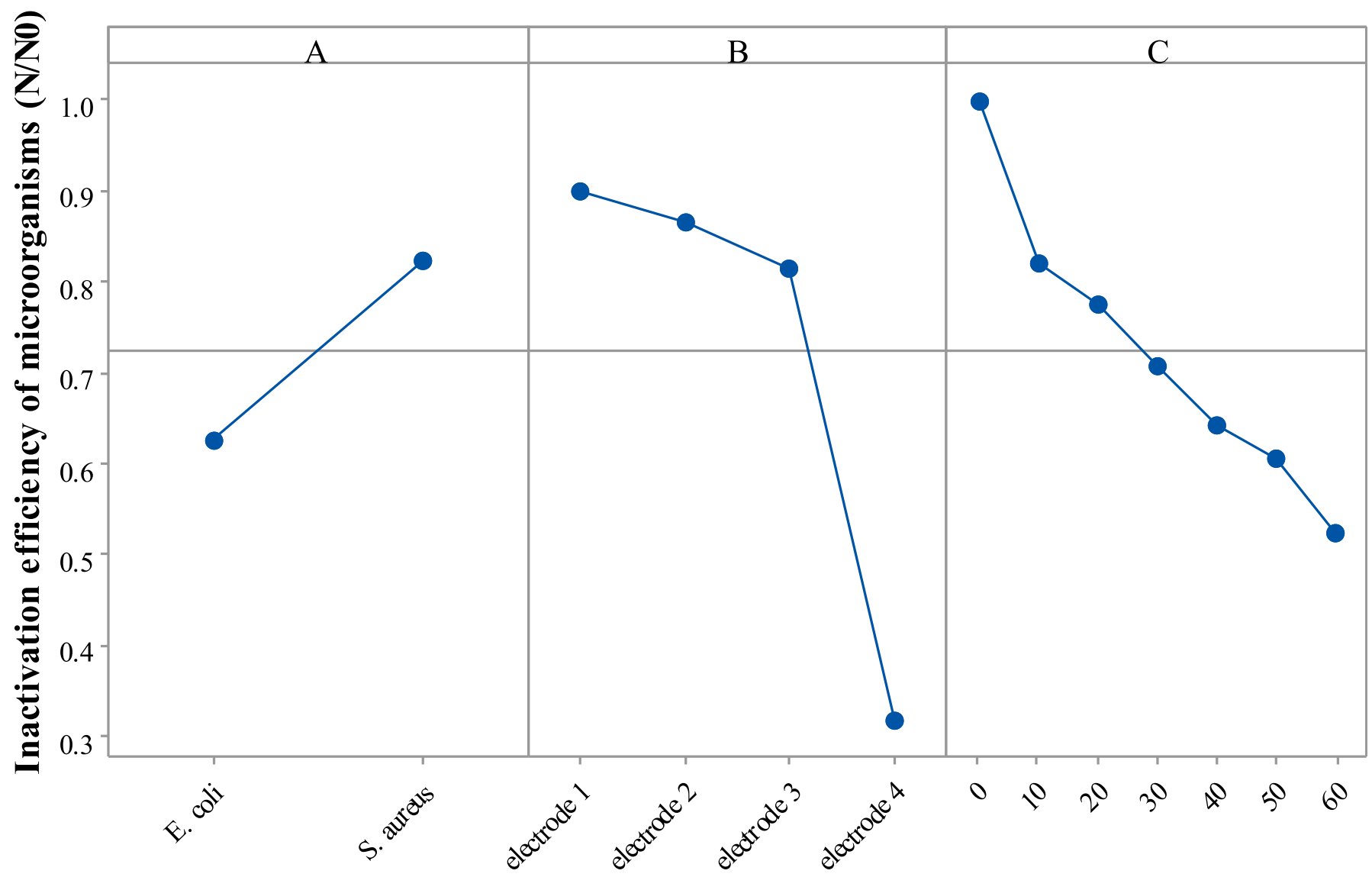

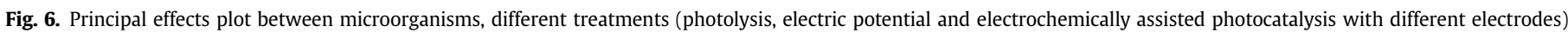
and the contact time for inactivation of E. coli and S. aureus. Where A: Microorganisms; B: Different treatments; C: contact time (min).

Table 4

Energy consumption of the lamps used in the electrochemically assisted photocatalyst reactor in 60 min of treatment with a dose of 1721.16 mWs $\mathrm{cm}^{-2}$.

\begin{tabular}{|c|c|c|c|c|c|c|}
\hline \multirow[t]{2}{*}{ Treatments } & \multicolumn{3}{|l|}{ E. coli } & \multicolumn{3}{|l|}{ S. aureus } \\
\hline & $\begin{array}{l}\text { Power consumption of } \\
\text { the lamps }\left(\mathrm{kWh} \mathrm{m}^{-3}\right)\end{array}$ & $\begin{array}{l}\text { Energy consumption of applied } \\
\text { electric potential }\left(\mathrm{kWh} \mathrm{m}^{-3}\right)\end{array}$ & $\begin{array}{l}\text { Total } \\
\text { consumption } \\
\left(\mathrm{kWh} \mathrm{m}^{-3}\right)\end{array}$ & $\begin{array}{l}\text { Power consumption of } \\
\text { the lamps }\left(\mathrm{kWh} \mathrm{m}^{-3}\right)\end{array}$ & $\begin{array}{l}\text { Energy consumption of applied } \\
\text { electric potential }\left(\mathrm{kWh} \mathrm{m}^{-3}\right)\end{array}$ & $\begin{array}{l}\text { Total } \\
\text { consumption } \\
\left(\mathrm{kWh} \mathrm{m}^{-3}\right)\end{array}$ \\
\hline Electrode 1 & 0.108 & $10.8 \times 10^{-3}$ & 0.119 & 0.108 & $10.8 \times 10^{-3}$ & 0.119 \\
\hline Electrode 2 & 0.108 & $10.8 \times 10^{-3}$ & 0.119 & 0.108 & $10.8 \times 10^{-3}$ & 0.119 \\
\hline Electrode 3 & 0.108 & $10.8 \times 10^{-3}$ & 0.119 & 0.108 & $10.8 \times 10^{-3}$ & 0.119 \\
\hline Electrode 4 & $0.018^{\mathrm{a}}$ & $1.8 \times 10^{-3 a}$ & 0.019 & 0.108 & $10.8 \times 10^{-3}$ & 0.119 \\
\hline
\end{tabular}

${ }^{\mathrm{a}}$ Energy consumption in $10 \mathrm{~min}$ of treatment considering a dose of $286.86 \mathrm{mWs} \mathrm{cm}{ }^{-2}$.

The same radiation dose $\left(1721.16 \mathrm{mWs} \mathrm{cm}^{-2}\right.$ ) was used to all other electrodes, but neither reached $100 \%$ inactivation values for both microorganisms after 60 min of treatment.

The energy consumption related to the electric potential during $10 \mathrm{~min}$ of treatment was $1.8 \times 10^{-3} \mathrm{kWhh} \mathrm{m}^{-3}$ and for the whole 60 min treatment was $10.8 \times 10^{-3} \mathrm{kWhh} \mathrm{m}^{-3}$. Therefore, the total electric energy consumption of lamps and electrical potential during treatment was $0.019 \mathrm{kWh} \mathrm{m}^{-3}$ for 10 min and $0.119 \mathrm{kWh}$ $\mathrm{m}^{-3}$ for $60 \mathrm{~min}$.

The total energy consumption achieved in this work to apply electrochemically assisted photocatalysis in $60 \mathrm{~min}$ $\left(0.119 \mathrm{kWh} \mathrm{m}^{-3}\right)$ is priced at 1.49 US cents (EIA, 2016), which is considered reasonably low for a water treatment procedure.

Most of this energy consumption is due to low-power and lowirradiation from UV-A black light bulbs. UV-A lamps do not harm humans, unlike UV-C or other high-output bulbs. The use of these
UV-A lamps is interesting from operational standpoint, as they do not cause burns or skin cancer. Moreover, the titanium used in the electrodes are extremely resistant to corrosion, improving the viability of electrochemically assisted photocatalytic procedures.

\section{Conclusions}

The electrochemically assisted photocatalytic activity was shown to be highly effective for treating water contaminated with gram-negative and gram-positive bacteria in comparison to photolysis. The thermally produced electrodes in a specific temperature, in rutile form, showed remarkable photocatalytic activity and were successfully used as photocatalysts for microbial inactivation using an electron drainage potential.

Among the electrodes tested in all electrochemically assisted photocatalysis, the most efficient inactivation occurred with the Ti/ 
$\mathrm{TiO}_{2}$ thermal electrode doped with Ag combining drainage electron from the applied potential plus the electron acceptor caused by the $\mathrm{Ag}$ itself. The inactivation was greater with gram-negative $E$. coli instead of gram-positive S. aureus.

The treatment also required low electrical power after $60 \mathrm{~min}$ due to the use of UV-A lamps, which provides much safer handling protocols compared to UV-C lamps, besides lower operation costs in terms of electric power consumption. In addition, the working electrode has a long lifespan. Thus, electrochemically assisted heterogeneous photocatalysis using silver-doped $\mathrm{Ti} / \mathrm{TiO} \mathrm{O}_{2}$ electrodes can be considered a highly promising and commercially viable alternative for the treatment of water contaminated with microorganisms.

This disinfection of water and development of new methods for the disinfection of drinking water are crucial for public health.

\section{Acknowledgements}

This work was supported by the CNPq.

\section{Appendix A. Supplementary data}

Supplementary data related to this article can be found at https://doi.org/10.1016/j.jenvman.2017.09.006.

\section{References}

Adhikari, A., Syamaladevi, R.M., Killinger, K., Sablani, S.S., 2015a. Ultraviolet-C light inactivation of Escherichia coli 0157:H7 and Listeria monocytogenes on organic fruit surfaces. Int. J. Food Microbiol. 210, 136-142. http://dx.doi.org/10.1016/ j.ijfoodmicro.2015.06.018.

Adhikari, S., Banerjee, A., Eswar, N.K., Sarkar, D., Madras, G., 2015b. Photocatalytic inactivation of $E$. Coli by $\mathrm{ZnO}-\mathrm{Ag}$ nanoparticles under solar radiation. RSC Adv. 5, 51067-51077. http://dx.doi.org/10.1039/C5RA06406F.

Amininezhad, S.M., Rezvani, A., Amouheidari, M., Amininejad, S.M., Rakhshani, S., 2015. The antibacterial activity of $\mathrm{SnO}_{2}$ nanoparticles against Escherichia coli and Staphylococcus aureus. Zahedan. J. Res. Med. Sci. 17, 29-33. http:// dx.doi.org/10.17795/zjrms-1053.

Augugliaro, V., Camera-Roda, G., Loddo, V., Palmisano, G., Palmisano, L., Soria, J., Yurdakal, S., 2015. Heterogeneous photocatalysis and photoelectrocatalysis: from unselective abatement of Noxious species to selective production of highvalue chemicals. J. Phys. Chem. Lett. 6, 1968-1981. http://dx.doi.org/10.1021/ acs.jpclett.5b00294.

Bahadur, J., Agrawal, S., Panwar, V., Parveen, A., Pal, K., 2016. Antibacterial properties of silver doped $\mathrm{TiO}_{2}$ nanoparticles synthesized via sol-gel technique. Macromol. Res. 24, 488-493. http://dx.doi.org/10.1007/s13233-016-4066-9.

Balasubramanian, G., Dionysiou, D.D., Suidan, M.T., Baudin, I., Laine, J.M., 2004. Evaluating the activities of immobilized $\mathrm{TiO}_{2}$ powder films for the photocatalytic degradation of organic contaminants in water. App. Catal. B Environ. 47, 73-84. http://dx.doi.org/10.1016/j.apcatb.2003.04.002.

Baram, N., Starosvetsky, D., Starovetsky, J., Epshtein, M., Armon, R., Ein-Eli, Y., 2007. Enhanced photo-efficiency of immobilized $\mathrm{TiO}_{2}$ catalyst via intense anodic bias. Electrochem. Commun. 9, 1684-1688. http://dx.doi.org/10.1016/ j.elecom.2007.03.017.

Baram, N., Starosvetsky, D., Starovetsky, J., Epshtein, M., Armon, R., Ein-Eli, Y., 2011. Photocatalytic inactivation of microorganisms using nanotubular $\mathrm{TiO}_{2}$. Appl. Catal. B Environ. 101, 212-219. http://dx.doi.org/10.1016/j.apcatb.2010.09.024.

Brugnera, M.F., Miyata, M., Zocolo, G.J., Leite, C.Q.F., Zanoni, M.V.B.A., 2013. A photoelectrocatalytic process that disinfects water contaminated with Mycobacterium kansasii and Mycobacterium avium. Water Res. 47, 6596-6605. http://dx.doi.org/10.1016/j.watres.2013.08.027.

Butterfield, I.M., Christensen, P.A., Hamnett, A., Shaw, K.E., Walker, G.M., Walker, S.A., Howarth, C.R., 1997. Applied studies on immobilized titanium dioxide as catalysts for the photoelectrochemical detoxification of water. J. App. Electrochem. 27, 385-395. http://dx.doi.org/10.1023/A:1018453402332.

Byrne, J.A., Davidson, A., Dunlop, P.S.M., Eggins, B.R., 2002. Water treatment using nano-crystalline $\mathrm{TiO}_{2}$ electrodes. J. Photochem. Photobiol. A Chem. 148, 365-374. http://dx.doi.org/10.1016/S1010-6030(02)00064-3.

Byrne, J.A., Dunlop, P.S.M., Hamilton, J.W.J., Fernández-Ibáñez, P., Polo-López, I., Sharma, P.K., Vennard, A.S.M., 2015. A Review of heterogeneous photocatalysis for water and surface disinfection. Molecules 20, 5574-5615. http://dx.doi.org/ 10.3390/molecules20045574.

Chaplin, B.P., 2014. Critical review of electrochemical advanced oxidation processes for water treatment applications. Environ. Sci.: Processes Imp. 16, 1182-1203. http://dx.doi.org/10.1039/C3EM00679D.

Cho, M., Cates, E.L., Kim, J.H., 2011. Inactivation and surface interactions of MS-2 bacteriophage in a $\mathrm{TiO}_{2}$ photoelectrocatalytic reactor. Water Res. 45, 2104-2111. http://dx.doi.org/10.1016/j.watres.2010.12.017.

Chong, M.N., Jin, B., Chow, C.W.K., Saint, C., 2010. Recent developments in photocatalytic water treatment technology: a review. Water Res. 44, 2997-3027. http://dx.doi.org/10.1016/j.watres.2010.02.039.

Christensen, P.A., Curtis, T.P., Egerton, T.A., Kosa, S.A.M., Tinlin, J.R., 2003. Photoelectrocatalytic and photocatalytic disinfection of $E$. coli suspensions by titanium dioxide. Appl. Catal. B Environ. 41, 371-386. http://dx.doi.org/10.1016/ S0926-3373(02)00172-8.

Christensen, P.A., Egerton, T.A., Kosa, S.A.M., Tinlin, J.R., Scott, K., 2005. The photocatalytic oxidation of aqueous nitrophenol using a novel reactor. J. App. Electrochem. 35, 683-692. http://dx.doi.org/10.1007/s10800-005-1366-8.

Claro, E.M.T., Bidoia, E.D., Moraes, P.B., 2016. A high-performance doped photocatalysts for inactivation of total coliforms in superficial waters using different sources of radiation. J. Environ. Manag. 177, 264-270. http://dx.doi.org/10.1016 | j.jenvman.2016.04.033.

Cutter, D.M., Miller, G., 2005. The role of public health improvements in health advances: the twentieth-century United States. Demography 42, 1-22. http:// dx.doi.org/10.3386/w10511.

Ding, Y., Yang, C., Zhu, L., Zhang, J., 2010. Photoelectrochemical activity of liquid phase deposited $\mathrm{TiO}_{2}$ film for degradation of benzotriazole. J. Hazard. Mater. 175, 96-103. http://dx.doi.org/10.1016/j.jhazmat.2009.09.037.

Ding, Z., Lu, G.Q., Greenfield, P.F., 2000. Role of the crystallite phase of $\mathrm{TiO}_{2}$ in heterogeneous photocatalysis for phenol oxidation in water. J. Phys. Chem. B 104, 4815-4820. http://dx.doi.org/10.1021/jp993819b.

Dunlop, P.S.M., McMurray, T.A., Hamilton, J.W.J., Byrne, J.A., 2008. Photocatalytic inactivation of Clostridium perfringens spores on $\mathrm{TiO}_{2}$ electrodes. J. Photochem. Photobiol. A Chem. 196, 113-119. http://dx.doi.org/10.1016/ j.jphotochem.2007.11.024.

EIA, 2016. Energy Information Administration. Electric Power Monthly. http://www. eia.gov/electricity/monthly/. (Accessed 2 January 2017).

Fan, M., Yang, C., Pu, W., Zhang, J., 2014. Liquid phase deposition of ZnO film for photoelectrocatalytic degradation of $p$-nitrophenol. Mater. Sci. Semicond. Process 17, 104-109. http://dx.doi.org/10.1016/j.mssp.2013.09.005.

Feng, Q.L., Wu, J., Chen, G.Q., Cui, F.Z., Kim, T.N., Kim, J.O., 2000. A mechanistic study of the antibacterial effect of silver ions on Escherichia coli and Staphylococcus aureus. J. Biomed. Mater. Res. 52, 662-668. http://dx.doi.org/10.1002/10974636(20001215)52:4<662::AID-JBM10>3.0.CO;2-3.

Foster, H.A., Ditta, I.B., Varghese, S., Steele, A., 2011. Photocatalytic disinfection using titanium dioxide: spectrum and mechanism of antimicrobial activity. J. Ind. Microbiol. Biotechnol. 90, 1847-1868. http://dx.doi.org/10.1007/s00253-0113213-7.

Grosser, M.R., Richardson, A.R., 2015. Method for preparation and electroporation of S. aureus and S. epidermidis. Methods Mol. Biol. 1373, 51-57. http://dx.doi.org/ 10.1007/7651_2014_183.

Gusmão, I.C.P., Moraes, P.B., Bidoia, E.D., 2009. A thin layer electrochemical cell for disinfection of water contaminated with Staphylococcus aureus. Braz. J. Microbiol. 40, 649-654. http://dx.doi.org/10.1590/S1517-83822009000300029.

Hanaor, D.A.H., Sorrell, C.C., 2011. Review of the anatase to rutile phase transformation. J. Mater. Sci. 46, 855-874. http://dx.doi.org/10.1007/s10853-0105113-0.

Harper, J.C., Christensen, P.A., Egerton, T.A., Curtis, T.P., Gunlazuardi, J., 2001. Effect of catalyst type on the kinetics of the photoelectrochemical disinfection of water inoculated with E. coli. J. App. Electrochem. 31, 623-628. http://dx.doi.org/ 10.1023/A:1017539328022.

Hosseini, S.M., Sarsari, I.A., Kameli, P., Salamati, H., 2015. Effect of Ag doping on structural, optical, and photocatalytic properties of ZnO nanoparticles. J. Alloys Compd. 640, 408-415. http://dx.doi.org/10.1016/j.jallcom.2015.03.136.

Jung, W.K., Koo, H.C., Kim, K.W., Shin, S., Kim, S.H., Park, Y.H., 2008. Antibacterial activity and mechanism of action of the silver ion in Staphylococcus aureus and Escherichia coli. App. Environ. Microbiol. 74, 2171-2178. http://dx.doi.org/ 10.1128/AEM.02001-07.

Krýsa, J., Zlámal, M., Waldner, G., 2007. Effect of oxidisable substrates on the photoelectrocatalytic properties of thermally grown and particulate $\mathrm{TiO}_{2}$ layers. J. App. Electrochem. 37, 1313-1319. http://dx.doi.org/10.1007/s10800-0079415-0.

Kumar, R., Rashid, J., Barakat, M.A., 2015. Zero valent Ag deposited $\mathrm{TiO}_{2}$ for the efficient photocatalysis of methylene blue under UV-C light irradiation. Colloids Interface Sci. Commun. 5, 1-4. http://dx.doi.org/10.1016/j.colcom.2015.05.001.

Li, G., Liu, Z.Q., Lu, J., Wang, L., Zhang, Z., 2009. Effect of calcination temperature on the morphology and surface properties of $\mathrm{TiO}_{2}$ nanotube arrays. App. Surf. Sci. 255, 7323-7328. http://dx.doi.org/10.1016/j.apsusc.2009.03.097.

Li, G., Nie, X., Chen, J., Jiang, Q., An, T., Wong, P.K., Zhang, H., Zhao, H., Yamashita, H. 2015. Enhanced visible-light-driven photocatalytic inactivation of Escherichia coli using $\mathrm{g}-\mathrm{C}_{3} \mathrm{~N}_{4} / \mathrm{TiO}_{2}$ hybrid photocatalyst synthesized using a hydrothermalcalcination approach. Water Res. 86, 17-24. http://dx.doi.org/10.1016/ j.watres.2015.05.053.

Litter, M.I., 1999. Heterogeneous photocatalysis: transition metal ions in photocatalytic systems. App. Catal. B: Environ. 23, 89-114. http://dx.doi.org/10.1016/ S0926-3373(99)00069-7.

Liu, H., Wensheng, Y., Ma, Y., Ye, X., Yao, J., 2003. Photocatalytic activity of pure rutile particles derived from a photo-assisted sol-gel method. New J. Chem. 27, 529-532. http://dx.doi.org/10.1039/B210465B.

Liu, Y., Wang, X., Yang, F., Yang, X., 2008. Excellent antimicrobial properties of mesoporous anatase $\mathrm{TiO}_{2}$ and $\mathrm{Ag} / \mathrm{TiO}_{2}$ composite films. Microporous 
Mesoporous Mater. 114, 431-439. http://dx.doi.org/10.1016/ j.micromeso.2008.01.032

Lopes, P.R.M., Montagnolli, R.N., Bidoia, E.D., 2012. Photocatalytic degradation of phenol by thermal titanium dioxide thin layer electrodes. Water Air Soil Pollut. 223, 3673-3688. http://dx.doi.org/10.1007/s11270-012-1140-6.

Matsunaga, T., Tomoda, R., Nakajima, T., Wake, H., 1985. Photoelectrochemical sterilization of microbial cells by semiconductor powders. FEMS Microbiol. Lett. 29, 211-214. http://dx.doi.org/10.1111/j.1574-6968.1985.tb00864.x.

Meireles, A., Giaouris, E., Simões, M., 2016. Alternative disinfection methods to chlorine for use in the fresh-cut industry. Food Res. Int. 82, 71-85. http:// dx.doi.org/10.1016/j.foodres.2016.01.021.

Molina, J., Sanchez-Salas, J.L., Zuniga, C., Mendoza, E., Cuahtecontzi, R., GarciaPerez, G., Gutierrez, E., Bandala, E.R., 2014. Low-temperature processing of thin films based on rutile $\mathrm{TiO}_{2}$ nanoparticles for UV photocatalysis and bacteria inactivation. J. Mater. Sci. 49, 786-793. http://dx.doi.org/10.1007/s10853-0137761-3.

Nakano, R., Hara, M., Ishiguro, H., Yao, Y., Ochiai, T., Nakata, K., Murakami, T., Kajioka, J., Sunada, K., Hashimoto, K., Fujishima, A., Kubota, Y., 2013. Broad spectrum microbicidal activity of photocatalysis by $\mathrm{TiO}_{2}$. Catalysts $3,310-323$. http://dx.doi.org/10.3390/catal3010310.

Pal, S., Tak, Y.K., Song, J.M., 2007. Does the antibacterial activity of silver nanoparticles depend on the shape of the nanoparticle? A study of the gramnegative bacterium Escherichia coli. App. Environ. Microbiol. 73, 1712-1720. http://dx.doi.org/10.1128/AEM.02218-06.

Parent, Y., Blake, D., Magrini-Bair, K., Lyons, C., Turchi, C., Watt, A., Wolfrum, E., Prairie, M., 1996. Solar photocatalytic process for the purification of water: state of development and barriers to commercialization. Sol. Energy 56, 429-437. http://dx.doi.org/10.1016/0038-092X(96)81767-1.

Parr, J.M.P., Kim, Y., 2016. Electrochemical silver dissolution and recovery as a potential method to disinfect drinking water to underprivileged societies. Environ. Sci. Water Res. Technol. 2, 304-311. http://dx.doi.org/10.1039/C5EW00274E.

Pham, T.-D., Lee, B.-K., 2014. Effects of Ag doping on the photocatalytic disinfection of $E$-coli in bioaerosol by $\mathrm{Ag}-\mathrm{TiO}_{2} / \mathrm{GF}$ under visible light. J. Colloid Interface Sci. 428, 24-31. http://dx.doi.org/10.1016/j.jcis.2014.04.030.

Plewa, M.J., Richardson, S.D., 2017. Disinfection by-products in drinking water, recycled water and wastewater: formation, detection, toxicity and health effects: preface. J. Environ. Sci. 58 (1) http://dx.doi.org/10.1016/j.jes.2017.07.017.

Plewa, M.J., Wagner, E.D., Richarson, S.D., 2017. TIC-Tox: a preliminary discussion on identifying the forcing agents of DBP-mediated toxicity of disinfected water. J. Environ. Sci. 58, 208-216. http://dx.doi.org/10.1016/j.jes.2017.04.014.

Quan, X., Chen, S., Su, J., Chen, J., Chen, G., 2004. Synergetic degradation of 2,4-D by integrated photo- and electrochemical catalysis on a Pt doped $\mathrm{TiO}_{2} / \mathrm{Ti}$ electrode. Sep. Purif. Technol. 34, 73-79. http://dx.doi.org/10.1016/S1383-5866(03)001771.
Rincón, A., Pulgarin, C., 2004. Bactericidal action of illuminated $\mathrm{TiO}_{2}$ on pure Escherichia coli and natural bacterial consortia: post-irradiation events in the dark and assessment of the effective disinfection time. App. Catal. B Environ. 49, 99-112. http://dx.doi.org/10.1016/j.apcatb.2003.11.013.

Scanlon, D.O., Dunnill, C.W., Buckeridge, J., Shevlin, S.A., Logsdail, A.K., Woodley, S.M., Catlow, C.R.A., Powell, M.J., Palgrave, R.G., Parkin, I.P., Watson, G.W., Keal, T.W., Sherwood, P., Walsh, A., Sokol, A.A., 2013. Band alignment of rutile and anatase $\mathrm{TiO}_{2}$. Nat. Mater. 12, 798-801. http://dx.doi.org/ 10.1038/nmat3697.

Scott-Emuakpor, E.O., Kruth, A., Todd, M.J., Raab, A., Paton, G.I., Macphee, D.E., 2012. Remediation of 2,4-dichlorophenol contaminated water by visible lightenhanced WO3 photoelectrocatalysis. Appl. Catal. B Environ. 123-124, 433-439. http://dx.doi.org/10.1016/j.apcatb.2012.05.010.

Sondi, I., Salopek-Sondi, B., 2004. Silver nanoparticles as antimicrobial agent: a case study on E. coli as a model for Gram-negative bacteria. J. Colloid Interface Sci. 275, 177-182. http://dx.doi.org/10.1016/j.jcis.2004.02.012

Sun, H., Li, G., Nie, X., Shi, H., Wong, P., Zhao, H., An, T., 2014. Systematic approach to in-depth understanding of photoelectrocatalytic bacterial inactivation mechanisms by tracking the decomposed building blocks. Environ. Sci. Technol. 48, 9412-9419. http://dx.doi.org/10.1021/es502471h.

Vijay, M., Ramachandran, K., Ananthapadmanabhan, P.V., Nalini, B., Pillai, B.C., Bondioli, F., Manivannan, A., Narendhirakannan, R.T., 2013. Photocatalytic inactivation of gram-positive and gram-negative bacteria by reactive plasma processed nanocrystalline $\mathrm{TiO}_{2}$ powder. Curr. Appl. Phys. 13, 510-516. http:// dx.doi.org/10.1016/j.cap.2012.09.014.

Wang, W., Huang, G., Yu, J.C., Wong, P.K., 2015a. Advances in photocatalytic disinfection of bacteria: development of photocatalysts and mechanisms. J. Environ. Sci. 34, 232-247. http://dx.doi.org/10.1016/j.jes.2015.05.003.

Wang, Y., Li, L., Huang, X., Li, Q., Li, G., 2015b. New insights into fluorinated $\mathrm{TiO}_{2}$ (brookite, anatase and rutile) nanoparticles as efficient photocatalytic redox catalysts. RSC Adv. 5, 34302-34313. http://dx.doi.org/10.1039/C4RA17076H.

Yang, J., Chen, C., Ji, H., Ma, W., Zhao, J., 2005. Mechanism of $\mathrm{TiO}_{2}$-assisted photocatalytic degradation of dyes under visible irradiation: photoelectrocatalytic study by $\mathrm{TiO}_{2}$-film electrode. J. Phys. Chem. B 109, 21900-21907. http:// dx.doi.org/10.1021/jp0540914.

Yu, H., Quan, X., Zhang, Y., Ma, N., Chen, S., Zhao, H., 2008. Electrochemically assisted photocatalytic inactivation of Escherichia coli under visible light using a $\mathrm{ZnIn}_{2} \mathrm{~S}_{4}$ film electrode. Langmuir 24, 7599-7604. http://dx.doi.org/10.1021/ la800835k.

Yuangpho, N., Le, S.T.T., Treerujiraphapong, T., Khanitchaidecha, W., Nakaruk, A., 2015. Enhanced photocatalytic performance of $\mathrm{TiO}_{2}$ particles via effect of anatase-rutile ratio. Physica E: low-dimens. Syst. Nanostruct. 67, 18-22. http:// dx.doi.org/10.1016/j.physe.2014.11.006. 